Article

\title{
Incidence of Fusarium Mycotoxins in Wheat and Maize from Albania
}

\author{
Dritan Topi $^{1,2}$ D, Janja Babič ${ }^{1}$, Katarina Pavšič-Vrtač ${ }^{1}$, Gabrijela Tavčar-Kalcher ${ }^{1, *}$ and Breda Jakovac-Strajn ${ }^{1}$ \\ 1 Institute of Food Safety, Feed and Environment, Veterinary Faculty, University of Ljubljana, Gerbičeva 60, \\ 1000 Ljubljana, Slovenia; dritan.topi@unitir.edu.al (D.T.); janja.babic@vf.uni-lj.si (J.B.); \\ katarina.vrtac@vf.uni-li.si (K.P.-V.); breda.jakovacstrajn@vf.uni-lj.si (B.J.-S.) \\ 2 Department of Chemistry, Faculty of Natural Sciences, University of Tirana, Boulevard Zogu 1, 25, \\ 1016 Tirana, Albania \\ * Correspondence: gabrijela.tavcar-kalcher@vf.uni-lj.si; Tel.: +386-1-4779-238
}

Citation: Topi, D.; Babič, J.;

Pavšič-Vrtač, K.; Tavčar-Kalcher, G.; Jakovac-Strajn, B. Incidence of Fusarium Mycotoxins in Wheat and Maize from Albania. Molecules 2021 26, 172. https://doi.org/10.3390/ molecules 26010172

Academic Editor: Derek J. McPhee Received: 30 November 2020 Accepted: 28 December 2020 Published: 31 December 2020

Publisher's Note: MDPI stays neutral with regard to jurisdictional clai$\mathrm{ms}$ in published maps and institutional affiliations.

Copyright: (C) 2020 by the authors. Licensee MDPI, Basel, Switzerland. This article is an open access article distributed under the terms and conditions of the Creative Commons Attribution (CC BY) license (https:// creativecommons.org/licenses/by/ $4.0 /)$.

\begin{abstract}
In this study, ten Fusarium toxins were analysed in wheat and maize commodities from Albania. In total, 71 samples of wheat and 45 samples of maize were collected from different producing regions. The analytical procedure consisted of a simple one-step sample extraction followed by the determination of toxins using liquid chromatography coupled with tandem mass spectrometry. Fusarium toxins were found in $23 \%$ of the analysed wheat samples and in $78 \%$ of maize samples. In maize samples, most often fumonisins $B_{1}$ (FB1) and $B_{2}$ (FB2) were found. They were present in $76 \%$ of samples. They were detected in all positive samples except in one with concentrations ranging from 59.9 to $16,970 \mu \mathrm{g} / \mathrm{kg}$. The sum of FB1 and FB2 exceeded the EU maximum permitted level $(4000 \mu \mathrm{g} / \mathrm{kg})$ in $31 \%$ of maize samples. In wheat samples, the only detected Fusarium mycotoxin was deoxynivalenol (DON), present in $23 \%$ of samples. In one sample with the concentration of $1916 \mu \mathrm{g} / \mathrm{kg}$, the EU maximum permitted level $(1250 \mu \mathrm{g} / \mathrm{kg})$ was exceeded. This is the first report on the presence of Fusarium toxins in wheat and maize grains cultivated in Albania.
\end{abstract}

Keywords: Fusarium toxins; deoxynivalenol; fumonisins; maize; wheat; Albania

\section{Introduction}

Mycotoxins are secondary metabolites with low molecular weight produced by filamentous fungi, or more specifically, moulds [1-8]. They contaminate cereals and other foods like nuts, spices, fruits, and their by-products [3,7]. In crops, they can be formed before harvesting, during harvest, drying, and storage in non-appropriate conditions [3,6-11]. They are mainly produced by the species Aspergillus, Penicillium, Alternaria, Claviceps, and Fusarium [3,9,11-15]. Fusarium species are probably the most dominant toxin-producing fungi in the temperate regions of the Northern hemisphere, responsible for Fusarium head blight disease in small grain cereals and ear rot disease in maize that may cause severe reductions in crop yield $[4,14,16,17]$. The main Fusarium toxins are type A and type B trichothecenes, zearalenone (ZEA), and fumonisins (FBs) $[4,12,18]$. The TypeA group includes T-2 toxin, HT-2 toxin, neosolaniol (NEO), and 4,15-diacetoxyscirpenol (DAS), while the Type-B group includes nivalenol (NIV), deoxynivalenol (DON), its 3-acetyl (3-AcDON) and 15-acetyl (15-AcDON) derivatives, and fusarenone-X [16].

Mycotoxins are relatively stable, and prevention methods to prevent mycotoxin contamination on the field before harvest, during harvesting, or storage have been developed, while their complete elimination from the contaminated material is difficult if not impossible $[6-10,16,17,19,20]$. However, sorting, cleaning, debranning, and thermal processing can significantly reduce mycotoxin concentrations in cereal products, whereas milling processes result in the repartitioning of mycotoxins in different milling fractions leading to a reduction in mycotoxin burden in the fractions used for human consumption [21,22]. The fate of 
different mycotoxins during these processes have been studied by several authors [22-27]. However, the results presented by Griessler et al. [20] reporting high contamination levels of FBs in complementary and complete feeding stuff prove that mycotoxins burden the fractions commonly used as animal feed $[21,22,26]$. Mycotoxin contamination in different food and feed commodities is an ongoing global threat and will be more significant due to the climate changes and increased exchanges in the food and feed global market $[11,15,19]$. Exposure to these compounds is a significant threat to human and animal health and is associated with different acute or chronic mycotoxicoses $[1,6,7,9,15,16,19,28]$.

In the European Union, the presence of Fusarium toxins in foodstuffs is regulated by Regulation (EC) No 1126/2007 [29] amending Regulation (EC) No 1881/2006 [30], and by Recommendation 2013/165/EU [31].

Several surveys on the worldwide contamination of Fusarium toxins in cereals and cereal products during the last decade indicate the importance of the problem that food safety is facing globally $[3-5,19,28,32]$. Several papers presented data on the Fusarium mycotoxins occurrence from European countries [9,18,20,33-50]. These data have shown high contamination rates, ranging from $20 \%$ to $100 \%$ for DON, $11 \%$ to $95 \%$ for $\mathrm{FBs}$, from $1 \%$ to $100 \%$ for T-2, from $4 \%$ to $60 \%$ for HT- 2 and from $71 \%$ to $100 \%$ for ZEA. However, the incidence of samples exceeding the EU maximum permitted levels was predominantly low. The authors often reported zero incidence or single samples exceeding maximum permitted levels [34,35,38,39,42,43,46]. Others, like Kirinčič et al. [47], reported only $2.4 \%$ of cereal and cereal product samples investigated in 2008-2012 in Slovenia and Van der Fels-Klerx et al. [41] reported $2.5 \%$ of wheat and $8.5 \%$ of oat and maize samples from countries of the Northern Europe investigated during the period 1989-2009 containing mycotoxins above the EU legal limits. Bryła et al. [48] reported $6.8 \%$ of cereal samples, cultivated in Poland in 2014, exceeding the maximum acceptable DON levels, and Udovicki et al. [9] reported $11.3 \%$ of samples from Serbia exceeding the EU maximum permitted levels during the period 2004-2016.

For the determination of mycotoxins, enzyme-linked immunosorbent assay (ELISA) $[40,42,44,49]$, gas chromatography-mass spectrometry $[35,38]$ and liquid chromatography coupled with ultraviolet $[20,47]$, fluorescence $[20,33,34,47]$ or mass spectrometry $[33,37,39,43,45-48]$ detectors were used. High-performance liquid chromatography with fluorescence detection (HPLC-FLD) is most frequently used for the quantitative determination of single mycotoxins, whereas liquid chromatography coupled with mass spectrometry allows for the simultaneous determination of multiple mycotoxins $[15,18,28]$.

This study aimed to get an insight into the occurrence of ten Fusarium mycotoxins (DON, 3-AcDON, 15-AcDON, ZEA, FB1, FB2, T-2, HT-2, DAS, and NEO) in two primary cereal commodities produced in Albania, maize, and wheat, both used as food and feed [51]. The study is the first-ever report on the presence of these mycotoxins in crop commodities from Albania. The data will expand the information on the occurrence of these mycotoxins in different grains from Southern Europe. We expected similar occurrence rates and concentrations as reported from the Southern European and Central European countries.

\section{Results and Discussion}

\subsection{Occurrence of Fusarium Toxins in Samples}

The samples containing one or more individual Fusarium toxins at concentrations above limit of quantification (LOQ) were considered as positive. Altogether, $44 \%$ of the analysed wheat and maize samples were contaminated. In the year 2014, the contamination rate was $58 \%$, while in 2015 it was $26 \%$.

In winter wheat samples from all regions, DON was the only detected Fusarium toxin, while the concentrations of the other nine Fusarium toxins were below LOQ $(50 \mu \mathrm{g} / \mathrm{kg})$. The number and the percentage of positive samples, the mean value of positive samples, the median, the minimum, and maximum determined concentrations are presented in Table 1. 
Table 1. Occurrence of deoxynivalenol (DON) in the wheat samples from the harvesting seasons 2014 and 2015.

\begin{tabular}{cccc}
\hline & $\mathbf{2 0 1 4}$ & $\mathbf{2 0 1 5}$ & $\mathbf{2 0 1 4 - 2 0 1 5}$ \\
\hline No. of samples & 35 & 36 & 71 \\
No. of positive samples & 12 & 4 & 16 \\
Incidence of positive samples $(\%)$ & 34 & 11 & 23 \\
Mean $(\mu \mathrm{g} / \mathrm{kg})$ & 540 & 657 & 569 \\
Median $(\mu \mathrm{g} / \mathrm{kg})$ & 512 & 257 & 477 \\
Minimum $(\mu \mathrm{g} / \mathrm{kg})$ & 112 & 198 & 112 \\
Maximum $(\mu \mathrm{g} / \mathrm{kg})$ & 919 & 1916 & 1916 \\
\hline
\end{tabular}

The maximum permitted level of $1250 \mu \mathrm{g} / \mathrm{kg}$ given in Regulation (EC) No 1126/2007 [29] for unprocessed cereals other than durum wheat, oats, and maize intended for human consumption was exceeded in only one of the wheat samples from the year 2015 with a DON concentration of $1916 \mu \mathrm{g} / \mathrm{kg}$.

The contamination rate in maize was much higher than in wheat. In Table 2, the incidence, mean value of positive samples, median, minimum, and maximum concentrations of Fusarium mycotoxins are presented for maize commodities. The main mycotoxins detected were FB1 and FB2. In the year 2015, they were the only mycotoxins found in maize. FB1 was present in all contaminated samples but one. In two-third of cases, both FB1 and FB2 were present, while in one-third of samples, only FB1 was detected. No sample contained only FB2. In the samples collected in 2014, DON, ZEA, and T-2 were also detected. ZEA was found in two samples from Kruja, and the T-2 toxin was detected in one sample from the Korça region. The results were in line with the global risk maps presented by Battilani and Logrieco [52]. According to the maps, Albania is among the countries with a low/absent risk regarding the DON contamination of wheat at harvest and among the countries with a high global risk of fumonisin contamination of maize. However, in the samples of barley and rye, no Fusarium toxins were detected.

Table 2. Occurrence of Fusarium toxins in maize samples from the harvesting seasons 2014 and 2015.

\begin{tabular}{cccccccc}
\hline & DON & ZEA & FB1 & FB2 & FB1+FB2 & T-2 & Total \\
\hline 2014 & & & & & & & \\
No. of samples & 31 & 31 & 31 & 31 & 31 & 31 & 31 \\
No. of positive samples & 11 & 2 & 25 & 22 & 25 & 1 & 26 \\
Mean $(\mu \mathrm{g} / \mathrm{kg})$ & 35 & 6.5 & 81 & 71 & 81 & 3.2 & 84 \\
Median $(\mu \mathrm{g} / \mathrm{kg})$ & 264 & 240 & 3460 & 2285 & 5470 & 106 & \\
Minimum $(\mu \mathrm{g} / \mathrm{kg})$ & 165 & 240 & 2694 & 1886 & 3669 & 106 & \\
Maximum $(\mu \mathrm{g} / \mathrm{kg})$ & 110 & 218 & 68.7 & 105 & 68.7 & 106 \\
2015 & 799 & 263 & 9873 & 9218 & 16,970 & 106 & \\
Toxin rate in positive samples (\%) & 42 & 7.7 & 96 & 85 & 96.3 & 3.8 & \\
No. of samples & & & & & & & \\
No. of positive samples & 14 & 14 & 14 & 14 & 14 & 14 & 14 \\
Mean $(\mu \mathrm{g} / \mathrm{kg})$ & 0 & 0 & 8 & 5 & 8 & 0 & 8 \\
Median $(\mu \mathrm{g} / \mathrm{kg})$ & - & - & 816 & 1573 & 1799 & - & \\
Minimum $(\mu \mathrm{g} / \mathrm{kg})$ & - & - & 308 & 479 & 389 & - & \\
Maximum $(\mu \mathrm{g} / \mathrm{kg})$ & - & - & 59.9 & 169 & 59.9 & - & \\
Toxin rate in positive samples $(\%)$ & 0.0 & 0.0 & 100 & 63 & 100 & 0.0 & \\
2014-2015 & & & & & & & \\
$\quad$ No. of samples & 45 & 45 & 45 & 45 & 45 & 45 & 45 \\
No. of positive samples & 11 & 2 & 34 & 27 & 34 & 1 & 35 \\
Incidence of positive samples $(\%)$ & 24 & 4.4 & 76 & 60 & 76 & 2.2 & 78 \\
\hline
\end{tabular}


Table 2. Cont.

\begin{tabular}{cccccccc}
\hline & DON & ZEA & FB1 & FB2 & FB1+FB2 & T-2 & Total \\
\hline Mean $(\mu \mathrm{g} / \mathrm{kg})$ & 264 & 240 & 2819 & 2153 & 4445 & 106 & \\
Median $(\mu \mathrm{g} / \mathrm{kg})$ & 165 & 240 & 790 & 1564 & 1162 & 106 & \\
Minimum $(\mu \mathrm{g} / \mathrm{kg})$ & 110 & 218 & 59.9 & 105 & 59.9 & 106 & \\
Maximum $(\mu \mathrm{g} / \mathrm{kg})$ & 799 & 263 & 9873 & 9218 & 16,970 & 106 & \\
Toxin rate in positive samples $(\%)$ & 32 & 5.9 & 97 & 79 & 97 & 2.9 & \\
\hline DON: deoxynivalenol; ZEA: zearalenone; FB1: fumonisin B $\mathrm{B}_{1} ; \mathrm{FB} 2:$ fumonisin $\mathrm{B}_{2}$. & & &
\end{tabular}

DON: deoxynivalenol; ZEA: zearalenone; FB1: fumonisin $\mathrm{B}_{1}$; FB2: fumonisin $\mathrm{B}_{2}$.

Concerning the sum of FB1 and FB2, the maximum permitted level of $4000 \mu \mathrm{g} / \mathrm{kg}$ laid down in Regulation (EC) No 1126/2007 [29] for unprocessed maize was exceeded in 12 samples (39\%) in 2014 and two samples (14\%) in 2015, altogether in $31 \%$ of maize samples. In six samples from the year 2015, the concentration was even higher than $10,000 \mu \mathrm{g} / \mathrm{kg}$. The concentrations of DON, ZEA, and T-2 toxin in maize samples were lower than the maximum permitted levels and the EU indicative level for the sum of T-2 and HT-2 in unprocessed maize intended for human consumption $(1750 \mu \mathrm{g} / \mathrm{kg}, 320 \mu \mathrm{g} / \mathrm{kg}$, and $200 \mu \mathrm{g} / \mathrm{kg}$, respectively) given in Regulation (EC) No 1126/2007 and Commission Recommendation 2013/165/EU [29,31].

The data on the presence of DON in winter wheat and maize according to the regions are shown in Tables 3 and 4, respectively. The incidence in wheat was similar in two western regions, Fieri and Lushnja, situated along the Adriatic Sea and the Elbasan region in the inner part of the country, but it was considerably lower in the eastern region Korça with the temperate continental climate (Table 3).

Table 3. The occurrence of DON in the wheat samples from the harvesting seasons 2014 and 2015 according to the regions.

\begin{tabular}{ccccc}
\hline & Fieri & Lushnja & Elbasan & Korça \\
\hline No. of samples & 11 & 22 & 10 & 28 \\
No. positive samples & 4 & 7 & 4 & 1 \\
Incidence of positive samples $(\%)$ & 36 & 32 & 40 & 3.6 \\
Mean $(\mu \mathrm{g} / \mathrm{kg})$ & 756 & 320 & 853 & 427 \\
Median $(\mu \mathrm{g} / \mathrm{kg})$ & 804 & 279 & 684 & 427 \\
Minimum $(\mu \mathrm{g} / \mathrm{kg})$ & 518 & 112 & 128 & 427 \\
Maximum $(\mu \mathrm{g} / \mathrm{kg})$ & 898 & 548 & 1916 & 427 \\
\hline
\end{tabular}

The concentrations were below the maximum permitted level of $1250 \mu \mathrm{g} / \mathrm{kg}$, except in one sample from Elbasan, where the concentration was $1916 \mu \mathrm{g} / \mathrm{kg}$. The incidence of DON in the maize varied from $0 \%$ (Fieri and Lushnja) to $64 \%$ (Kruja) (Table 4). All the concentrations were far below the maximum permitted level of $1750 \mu \mathrm{g} / \mathrm{kg}$. However, the incidence and concentrations of FBs were higher. In Fieri, Lushnja, and Kruja, the mean concentrations (sum of FB1 and FB2) were higher than the maximum permitted level $(4000 \mu \mathrm{g} / \mathrm{kg})$. Concerning the median values of positive samples, the order of the regions was Fieri > Lushnja > Kruja > Elbasan > Korça, situated from the west of the country with a hot-summer Mediterranean climate to the east of the country belonging to the continental climate. However, the highest concentration was determined in a sample from Korça. As mentioned before, the maximum permitted concentration was exceeded in 14 samples. Most of these samples were from Lushnja and Kruja, where $50 \%$ and $36 \%$ of samples, respectively, were non-compliant. However, the incidence of contaminated maize samples containing at least one mycotoxin was similar in the Fieri, Lushnja, and Korça regions (57\%, $70 \%$, and $64 \%$, respectively), while it was higher in the Kruja and Elbasan regions ( $91 \%$ and $100 \%$, respectively). 
Table 4. Occurrence of DON and FBs (sum of FB1 and FB2) in maize samples from the harvesting seasons 2014 and 2015 for each region.

\begin{tabular}{|c|c|c|c|c|c|c|c|c|c|c|c|c|c|c|c|}
\hline & \multicolumn{3}{|c|}{ Fieri } & \multicolumn{3}{|c|}{ Lushnja } & \multicolumn{3}{|c|}{ Kruja } & \multicolumn{3}{|c|}{ Elbasan } & \multicolumn{3}{|c|}{ Korça } \\
\hline & DON & FBs & Total & DON & FBs & Total & DON & FBs & Total & DON & FBs & Total & DON & FBs & Total \\
\hline No. of samples & 7 & 7 & 7 & 10 & 10 & 10 & 11 & 11 & 11 & 6 & 6 & 6 & 11 & 11 & 11 \\
\hline No. positive samples & 0 & 4 & 4 & 0 & 7 & 7 & 7 & 10 & 10 & 3 & 5 & 6 & 1 & 7 & 7 \\
\hline Incidence of positive samples (\%) & 0.0 & 57 & 57 & 0.0 & 70 & 70 & 64 & 91 & 91 & 50 & 83 & 100 & 9.1 & 64 & 64 \\
\hline Mean $(\mu \mathrm{g} / \mathrm{kg})$ & - & 6511 & - & - & 5959 & - & 237 & 4894 & - & 361 & 1837 & - & 167 & 3813 & - \\
\hline Median $(\mu \mathrm{g} / \mathrm{kg})$ & - & 6615 & - & - & 6205 & - & 149 & 3288 & - & 343 & 903 & - & 167 & 874 & - \\
\hline Minimum $(\mu \mathrm{g} / \mathrm{kg})$ & - & 255 & - & - & 389 & - & 110 & 83.8 & - & 160 & 594 & - & 167 & 60 & - \\
\hline Maximum $(\mu \mathrm{g} / \mathrm{kg})$ & - & 12,559 & - & - & 14,566 & - & 799 & 13,906 & - & 579 & 6117 & - & 167 & 16,967 & - \\
\hline No. of samples above EU max level & 0 & 2 & - & 0 & 5 & - & 0 & 4 & - & 0 & 1 & - & 0 & 2 & - \\
\hline Samples above EU max level (\%) & 0 & 29 & - & 0 & 50 & - & 0 & 36 & - & 0 & 17 & - & 0 & 18 & - \\
\hline
\end{tabular}


The co-occurrence of two or more Fusarium toxins was detected only in maize samples. Of 34 contaminated samples, five samples (15\%) contained one mycotoxin, 19 samples (56\%) contained two mycotoxins, nine samples (26\%) contained three mycotoxins, and one sample $(3 \%)$ contained four mycotoxins. This finding is consistent with the results presented by Jakovac-Strajn et al. [34], Ibáñez-Vea et al. [38], Stanković et al. [40], Juan et al. [43], Alkadri et al. [46], and Kirinčič et al. [47], who reported a high percentage of samples containing more than one mycotoxin. FB1 and FB2 co-occurred most often. They were present together in 18 of the 19 samples containing two mycotoxins. While in eight of the nine samples containing three mycotoxins, DON, FB1, and FB2 co-occurred, in one sample, DON, ZEA, and FB1 were present. In the sample with four mycotoxins, DON, ZEA, FB1, and FB2 were present. However, the most common co-occurrence of DON, 3-AcDON, and 15-AcDON reported by Ibáñez-Vea et al. [38] and Van Der Fels-Klerx et al. [41] was not recognized in our study.

The incidence rate and the mean concentrations of mycotoxins were higher in the year 2014 than in 2015 in both commodities. However, the mycotoxin pattern was different between wheat and maize, which could be dependent on Fusarium species that infect these two cereals [4]. Both the production of mycotoxins and Fusarium profile are dependent on several factors, primarily climatic conditions, particularly rainfall and temperature at the flowering stage, but also agronomic factors, such as tillage, nitrogen fertilization, use of fungicides, crop rotation, and host genotype $[4,16,17]$. These data were not collected in the study and therefore no conclusions can be drawn on the correlation of the contamination rate and mycotoxin pattern on geographical and climatic conditions. However, the available meteorological data show that the annual average temperatures and precipitations were above the long-term average in all regions in both years. Furthermore, the incidence of mycotoxins in the samples from the Korça region seems lower than with samples from the other investigated western plain regions close to the Adriatic Sea. Considering that the level of agricultural development was similar in all investigated regions, the lower incidence can be explained by the climate differences between the temperate climate Korça and the typical Mediterranean climate regions of the western part of the country.

\subsection{Comparison with Fusarium Mycotoxins Occurrence in Other Countries}

Our result of the incidence of DON in wheat $(23 \%)$ is comparable with the results presented by Griessler et al. [20], Škrbić et al. [37], Van Der Fels-Klerx et al. [41], and Juan et al. [43] (Table 5). Škrbić et al. [37] reported the incidence rate of $27.8 \%$ in the harvesting year 2007. A similar contamination rate was reported in Italy (28.1\%) [43], Southern Europe (27.6\%) [20], and in the sampling years before 2009 from Finland (29.9\%), Norway (29.4\%) and Sweden (20.6\%) [41], while in other reports the incidence rates were higher i.e., 100\% in the year 2011 in Norway [45], 96.7\% in the year 2013 in Finland [18], $71.4 \%$ in the Netherlands [41], 46.5\% in Poland [48], 74.1\% in Catalonia, Spain [35], 95\% in Navarra, Spain [38], 59.6\% in Italy [46], 75\% and 68.8\% in Slovenia [34,47], 65\% in Croatia [44], 85.7\%-93.3\% in Serbia [40] as well as 73.1\% in Romania [42]. 
Table 5. Occurrence of DON in wheat from different studies.

\begin{tabular}{|c|c|c|c|c|c|c|c|c|c|}
\hline Country & $\begin{array}{c}\text { Year of } \\
\text { Sampling }\end{array}$ & $\begin{array}{l}\text { Method of } \\
\text { Analysis }\end{array}$ & $\underset{(\mu \mathrm{LO} / \mathrm{kg})}{\mathrm{LOD} / \mathrm{LOQ}}$ & $\begin{array}{c}\text { Number of } \\
\text { Samples }\end{array}$ & $\begin{array}{c}\text { Positive } \\
\text { Sample Rate } \\
(\%)\end{array}$ & $\begin{array}{c}\text { Mean } \\
(\mu \mathrm{g} / \mathrm{kg})\end{array}$ & $\begin{array}{c}\text { Median } \\
(\mu \mathrm{g} / \mathrm{kg})\end{array}$ & $\underset{(\mu \mathrm{g} / \mathrm{kg})}{\operatorname{Max}}$ & Reference \\
\hline Albania & 2014-2015 & LC-MS/MS & $15 / 50$ & 71 & 23 & $569^{a}$ & $477^{\mathrm{a}}$ & 1916 & This study \\
\hline Finland & 2000-2009 & - & $100 /-$ & 338 & 29.9 & - & 0 & 5865 & {$[41]$} \\
\hline Netherlands & 1989-2009 & - & $100 /-$ & 940 & 71.4 & - & 220 & 10,000 & \\
\hline Norway & 1990-2009 & - & $100 /-$ & 832 & 29.4 & - & 0 & 1552 & \\
\hline Sweden & 1999-2009 & - & $100 /-$ & 554 & 20.6 & - & 0 & 890 & \\
\hline Norway & 2011 & LC-MS/MS & - & 28 & 100 & - & 383 & 1400 & [45] \\
\hline Finland & 2013 & LC-MS/MS & $1.3 / 3.9$ & 30 & 96.7 & 866 & - & 5510 & [18] \\
\hline Poland & 2014 & UHPLC-HRMS & $-/ 25$ & 99 & 46.5 & $25-960^{a}$ & $25-694^{a}$ & 2975 & [48] \\
\hline Southern Europe & $2005-2009$ & ELISA & $-/ 250$ & 29 & 27.6 & 275 & $602^{a}$ & 2232 & [20] \\
\hline Italy & 2009-2010 & HPLC-MS/MS & $5 / 15$ & 47 & 59.6 & $172^{a}$ & - & 1230 & [46] \\
\hline Italy & 2012 & LC-MS/MS & $5 / 10$ & 57 & 28.1 & $10.96^{\mathrm{a}}$ & - & 99.6 & [43] \\
\hline Spain (Catalonia) & 2008 & GC-MS & $-/ 41$ & $27^{b}$ & 74.1 & $190^{\mathrm{a}}$ & $157^{\mathrm{a}}$ & 437 & [35] \\
\hline Spain (Navarra) & 2007-2008 & GC-MS & $-/ 10$ & 123 & 95 & $59.6^{\mathrm{a}}$ & $21.4^{\mathrm{a}}$ & 1111.3 & [38] \\
\hline Slovenia & 2007-2008 & GC-MS & $50 / 100$ & 20 & 75 & $849^{a}$ & $420^{a}$ & 3700 & [34] \\
\hline Slovenia & 2008-2012 & HPLC-UV & $-/ 50$ & $80^{c}$ & 68.8 & $477^{\mathrm{a}}$ & - & 3070 & [47] \\
\hline Croatia & 2011 & ELISA & $20.5 /-$ & 51 & 65 & $223^{a}$ & - & 278 & [44] \\
\hline Serbia & 2005,2007 & ELISA & $-/-$ & 103 & $85.7-93.3$ & $283-606^{a}$ & - & $1090-3306$ & [40] \\
\hline Serbia & 2007 & LC-MS/MS & $0.3 / 1$ & 54 & 27.8 & 33 & - & 309 & [37] \\
\hline Western Romania & 2010-2011 & ELISA & $110 / 220$ & 52 & $19.2-73.1$ & $763.6-2263^{a}$ & - & $1440-3390$ & [42] \\
\hline
\end{tabular}

${ }^{\mathrm{a}}$ only positive samples considered; ${ }^{\mathrm{b}}$ wheat flakes; ${ }^{\mathrm{c}}$ wheat and wheat products; LOD: limit of detection; LOQ: limit of quantification. 
The maximum level of DON in the wheat commodity in our study was much lower than in a significant number of reports from other countries. The highest reported levels were $10,000 \mu \mathrm{g} / \mathrm{kg}$ in a sample from the Netherlands [41], $5865 \mu \mathrm{g} / \mathrm{kg}$ and $5510 \mu \mathrm{g} / \mathrm{kg}$ in samples from Finland [18,41], $3306 \mu \mathrm{g} / \mathrm{kg}$ in a sample from Serbia [40], and $3700 \mu \mathrm{g} / \mathrm{kg}$ [34] and $3070 \mu \mathrm{g} / \mathrm{kg}$ [47] in samples from Slovenia. However, in some studies from Poland, Croatia, Serbia, and Spain, respectively, the highest reported levels were at $100 \mu \mathrm{g} / \mathrm{kg}$ [48], $278 \mu \mathrm{g} / \mathrm{kg}$ [44], $309 \mu \mathrm{g} / \mathrm{kg}$ [37], and $437 \mu \mathrm{g} / \mathrm{kg}$ [35].

The incidence rate of DON in maize samples (24\%) was comparable with incidence data for maize commodity from Slovenia (35.3\%) [47] or Romania (42.9\%) [49], but lower than the incidence rates of $71 \%-87.9 \%$ in this crop commodity in other studies reporting data from Slovenia [34], Spain [35]), Northern Europe [41] and Croatia [44] (Table 6). The highest determined level of DON $(799 \mu \mathrm{g} / \mathrm{kg})$ was comparable to the highest reported level in the study from Spain $(580 \mu \mathrm{g} / \mathrm{kg})$ [35], but lower than in all other studies in the range of 1269.9 to $14,420 \mu \mathrm{g} / \mathrm{kg}$.

The incidence rate of ZEA in maize samples was $4.4 \%$, similar to data from Romania (7.1\%) [49], but lower than in all other studies where the occurrence rate of $13.3 \%-78 \%$ was given (Table 6). The highest determined level of ZEA in our study ( $263 \mu \mathrm{g} / \mathrm{kg}$ ) was higher than the data reported by Manova and Mladenova [33] and Gagiu et al. [49], but much lower than in all other studies given in Table $6(611-1000 \mu \mathrm{g} / \mathrm{kg})$. The contamination rate of T-2 was similarly low, as in the reports of Jakovac-Strajn et al. [34] and Cano-Sancho et al. [35]; however, Pleadin et al. [44] reported a contamination rate of 57\%.

The incidence of FBs (sum of FB1 and FB2) in our study (76\%) was found to be similar with the published data on the incidence from Croatia (90\%) [44] but was higher than in the other studies $[34,47]$. The highest determined level $(16,970 \mu \mathrm{g} / \mathrm{kg})$ is comparable to the concentration reported by Kirinčič et al. [47]. However, both values are much higher than those reported elsewhere $[33,34,44]$. 
Table 6. Occurrence of Fusarium toxins in maize samples from different studies.

\begin{tabular}{|c|c|c|c|c|c|c|c|c|c|c|}
\hline Country & $\begin{array}{c}\text { Year of } \\
\text { Sampling }\end{array}$ & $\begin{array}{l}\text { Method of } \\
\text { Analysis }\end{array}$ & $\begin{array}{c}\text { LOD/LOQ } \\
(\mu \mathrm{g} / \mathrm{kg})\end{array}$ & Toxin & $\begin{array}{l}\text { Number of } \\
\text { Samples }\end{array}$ & $\begin{array}{c}\text { Positive Sample } \\
\text { Rate (\%) }\end{array}$ & $\begin{array}{l}\text { Mean } \\
(\mu \mathrm{g} / \mathrm{kg})\end{array}$ & $\begin{array}{l}\text { Median } \\
(\mu \mathrm{g} / \mathrm{kg})\end{array}$ & $\begin{array}{c}\operatorname{Max} \\
(\mu \mathrm{g} / \mathrm{kg})\end{array}$ & Reference \\
\hline \multirow[t]{4}{*}{ Albania } & 2014-2015 & LC-MS/MS & $15 / 50$ & DON & 45 & 24 & $264^{\mathrm{a}}$ & $165^{a}$ & 799 & This study \\
\hline & & & & ZEA & 45 & 4.4 & $240^{\mathrm{a}}$ & $240^{\mathrm{a}}$ & 263 & \\
\hline & & & & $\mathrm{T}-2$ & 45 & 2.2 & $106^{\mathrm{a}}$ & $106^{\mathrm{a}}$ & 106 & \\
\hline & & & & $\mathrm{FB} 1+\mathrm{FB} 2$ & 45 & 76 & $4445^{a}$ & $1162^{a}$ & 16,970 & \\
\hline \multirow[t]{2}{*}{ Netherlands } & 1989-2009 & - & $100 /-$ & DON & 142 & 84.5 & - & 500 & 5000 & [41] \\
\hline & & & $50 /-$ & ZEA & 147 & 37.4 & - & 0 & 1000 & \\
\hline Sweden & 1999-2009 & - & $100 /-$ & $\mathrm{DON}$ & 5 & 40.0 & - & 187.5 & 420.0 & \\
\hline \multirow[t]{3}{*}{ Spain (Catalonia) } & 2008 & GC-MS & $-/ 45$ & DON & 65 & 75.4 & $109^{a}$ & $93^{a}$ & 580 & [35] \\
\hline & & & $-/ 57$ & $\mathrm{~T}-2$ & 65 & 0 & - & - & - & \\
\hline & & & $-/ 30$ & HT-2 & 65 & 6.2 & $41^{\mathrm{a}}$ & $34^{\mathrm{a}}$ & 65 & \\
\hline \multirow[t]{5}{*}{ Slovenia } & 2007-2008 & GC-MS & $50 / 100$ & DON & 58 & 87.9 & $1355^{a}$ & $480^{a}$ & 14,420 & [34] \\
\hline & & & $20 / 50$ & ZEA & 58 & 50.0 & $199^{a}$ & $180^{a}$ & 640 & \\
\hline & & & $60 / 200$ & $\mathrm{FB} 1+\mathrm{FB} 2$ & 58 & 39.7 & $1336^{a}$ & $468^{a}$ & 6489 & \\
\hline & & & $50 / 100$ & $\mathrm{~T}-2$ & 58 & 1.7 & $290^{\mathrm{a}}$ & $290^{\mathrm{a}}$ & 290 & \\
\hline & & & $50 / 100$ & HT-2 & 58 & 1.7 & $2300^{a}$ & $2300^{a}$ & 2300 & \\
\hline \multirow[t]{3}{*}{ Slovenia } & 2008-2012 & HPLC-UV & $-/ 50$ & DON & $34^{b}$ & 35.3 & $1328^{\mathrm{a}}$ & - & 11,800 & [47] \\
\hline & & & $-/ 5$ & ZEA & $34^{b}$ & 17.6 & $823^{a}$ & - & 4578 & \\
\hline & & & $-/ 200$ & $\mathrm{FB} 1+\mathrm{FB} 2$ & $34^{b}$ & 23.5 & $4092^{a}$ & - & 27,483 & \\
\hline \multirow{4}{*}{ Croatia } & 2011 & ELISA & $20.5 /-$ & DON & 63 & 71 & $1565^{a}$ & - & 2942 & {$[44]$} \\
\hline & & & $2.1 /-$ & ZEA & 63 & 78 & $187^{\mathrm{a}}$ & - & 611 & \\
\hline & & & $24.5 /-$ & $\mathrm{FB}$ & 63 & 90 & $1756^{a}$ & - & 4438 & \\
\hline & & & $4.1 /-$ & $\mathrm{T}-2$ & 63 & 57 & $24^{\mathrm{a}}$ & - & 42 & \\
\hline Serbia & 2008-2015 & ELISA & $75 /-$ & $\mathrm{FB} 1+\mathrm{FB} 2$ & 614 & $34.4-100$ & $580-4310$ & $<75-2590$ & 41,440 & [50] \\
\hline \multirow[t]{2}{*}{ Bulgaria } & 2007 & HPLC & $17.7 / 58.8$ & ZEA & 19 & 21.1 & $80.6^{a}$ & - & 148.0 & [33] \\
\hline & & LC-MS/MS & $27.3 / 90.8$ & $\mathrm{FB} 1+\mathrm{FB} 2$ & 19 & 94.7 & 1150 & - & 4050 & \\
\hline \multirow[t]{2}{*}{ Romania } & 2012-2015 & ELISA & 18.5 & $\mathrm{DON}$ & $91^{c}$ & 42.9 & 82.39 & $<18.5$ & 1269.94 & [49] \\
\hline & & & 1.75 & ZEA & $84^{c}$ & 7.1 & $1.92^{\mathrm{a}}$ & - & 7.05 & \\
\hline
\end{tabular}

${ }^{a}$ only positive samples considered; ${ }^{b}$ maize and maize products; ${ }^{c}$ cereals and cereal-based food. 


\section{Materials and Methods}

\subsection{Sample Collection}

Samples were collected from different regions, taking into account the country's geography and production. According to the Food and Agriculture Organization (FAO) of the United Nations database [51], which provides data relating to food and agriculture for countries worldwide, the yearly production of wheat, maize, barley, and rye in Albania is around 275,000 tonnes, 380,000 tonnes, 7500 tonnes, and 3000 tonnes, respectively. Correspondingly, mainly wheat and maize samples were collected, but also a few samples of barley and rye. Winter wheat and maize were sampled after their respective harvesting seasons from five main agriculture regions in Albania: Fieri, Lushnja, Kruja, Elbasan, and Korça. The sampling of wheat commodity in the regions of Fieri, Lushnja, Elbasan, and Kruja was carried out in June 2014 and June 2015, while in the Korça region it was performed in July 2014 and July 2015. Maize samples were collected in October 2014 and October 2015. The samples were taken from the warehouses. The weather conditions were not recorded at the time of sampling or during the growth of the grain. The sampling procedure was carried out according to the Commission Regulation (EC) No 401/2006 [53] to ensure representative samples. However, the study was performed as a research, not as a part of official control. Seventy-one wheat and 45 maize samples were collected in two harvesting seasons, 2014 and 2015. Specifically, 35 wheat and 31 maize samples belonged to the 2014 harvesting year, while 36 wheat and 14 maize samples were from 2015. In the year 2015, we were able to obtain the consent of only 14 farms for the maize samples to be taken. In addition, in Korça and Fieri, seven samples of barley and two samples of rye were collected (two samples of rye and five samples of barley in 2014, and two samples of barley in 2015).

\subsection{Standards and Chemicals}

Mixed trichothecene standard solution in acetonitrile (DON, 3-AcDON, 15-AcDON, T2, HT-2, DAS, and NEO) produced by Trilogy (Washington, MO, USA) and single standards of ZEA, FB1, and FB2 (Romer Labs, Tulln, Austria) were used. Stock standard solutions and the mixed working standard solutions were prepared in acetonitrile and stored in amber glass vials at $-20^{\circ} \mathrm{C}$. The concentrations of stock standard solutions were $100 \mu \mathrm{g} / \mathrm{mL}$ (DON, 3-AcDON, 15-AcDON, T-2, HT-2, DAS and NEO) and $50 \mu \mathrm{g} / \mathrm{mL}$ (ZEA, FB1, FB2). Acetonitrile, methanol, acetic acid (Sigma-Aldrich, Steinheim, Germany), and ammonium acetate (Merck, Darmstadt, Germany) were p.a. or LC-MS grade purity. Deionized water was prepared using a Milli-Q system (Millipore, Bedford, MA, USA).

\subsection{Sample Preparation}

For the simultaneous determination of mycotoxins (DON, 3-AcDON, 15-AcDON, ZEA, FB1, FB2, T-2, HT-2, DAS, and NEO), a procedure described in detail by Topi et al. [54] was used. The procedure consisting of the extraction of mycotoxins from ground cereal samples and liquid chromatography-tandem mass spectrometry (LC-MS/MS) was based on the analytical procedures of Rasmussen et al. [55], Lattanzio et al. [56] and Schenzel et al. [57]. Samples were ground to a particle size of $1 \mathrm{~mm}$ using a laboratory mill Retsch ZM 100 (Haan, Germany). Ten grams of a sample were shaken with $100 \mathrm{~mL}$ of an acetonitriledeionised water mixture $(84+16)$ for $1 \mathrm{~h}$ using an IKA HS 501 digital linear shaker (IKA Labortechnik, Staufen, Germany). A total of $4 \mathrm{~mL}$ of the filtered extract was evaporated under vacuum to dryness using a Syncore Polyvap system (Büchi, Flawil, Switzerland). For mycotoxin concentrations above the calibration range, the filtered extracts were diluted for further work. The dry residue was reconstituted in $0.5 \mathrm{~mL}$ of a methanol-deionised water mixture $(20+80)$. An aliquot-10 $\mu \mathrm{L}$ of the solution-was injected into the UPLCMS/MS system (Acquity UPLC H Class system) coupled with a triple-quadrupole mass spectrometer (Xevo TQ MS) equipped with an electrospray ionization (ESI) interface and MassLynx software for data collection and processing (Waters, Milford, MA, USA). The vials were kept in the autosampler at $15{ }^{\circ} \mathrm{C}$. For the matrix-matched calibration, $4 \mathrm{~mL}$ 
portions of the filtered extracts were spiked with the appropriate amounts of standard solutions and prepared along the samples.

\subsection{LC-MS/MS Analysis}

For the LC-MS/MS determination, the conditions reported by Topi et al. [54] were applied. Chromatographic separation was performed on a Zorbax Eclipse Plus C18 Rapid Resolution HD column, $2.1 \times 100 \mathrm{~mm}, 1.8 \mu \mathrm{m}$ (Agilent, Santa Clara, CA, USA). The mobile phase consisted of two components mixed in gradient mode. Component $\mathrm{A}$ was deionized water and component $\mathrm{B}$ was methanol, both containing $0.5 \%$ acetic acid and $2.5 \mathrm{mM}$ ammonium acetate. The starting composition of the eluent was $95 \% \mathrm{~A}$ and $5 \%$ B. The portion of component B was linearly increased to $40 \%$ within 4 min and further increased to $70 \%$ within the next $8 \mathrm{~min}$. This latter composition was held for $4 \mathrm{~min}$, and then component B was increased to $90 \%$ in $1.5 \mathrm{~min}$. The proportion of component B was held at $90 \%$ for $2.5 \mathrm{~min}$ and then returned back to $5 \%$ in $1 \mathrm{~min}$. The final composition was held for $4 \mathrm{~min}$. The mobile phase flow rate was $0.3 \mathrm{~mL} / \mathrm{min}$, and the column temperature was $40{ }^{\circ} \mathrm{C}$. MS /MS analysis was carried out in multiple reaction monitoring (MRM) mode switching between positive and negative ionisation mode during a single run. The capillary voltage was $3.4 \mathrm{kV}(\mathrm{ESI}+)$ and $3.0 \mathrm{kV}(\mathrm{ESI}-)$, the desolvation temperature was $500{ }^{\circ} \mathrm{C}$, the ion source temperature was $150{ }^{\circ} \mathrm{C}$ and the collision cell voltage was $20 \mathrm{~V}$. Specific MS/MS parameters related to determined mycotoxins (retention times, ionisation mode, and monitored transitions) are presented in Table 7.

Table 7. Retention times of Fusarium toxins, ionization mode and monitored transitions.

\begin{tabular}{cccccc}
\hline Analyte & $\begin{array}{c}\text { Ionization } \\
\text { Mode }\end{array}$ & $\begin{array}{c}\text { Retention } \\
\text { Time }(\mathbf{m i n})\end{array}$ & $\begin{array}{c}\text { Precursor } \\
\text { Ion }(\mathbf{m} / \mathbf{z})\end{array}$ & $\begin{array}{c}\text { Quantifier } \\
\text { Ion }(\boldsymbol{m} / \mathbf{z})\end{array}$ & $\begin{array}{c}\text { Qualifier Ion } \\
(\mathbf{m} / \mathbf{z})\end{array}$ \\
\hline DON & ESI+ & 3.14 & 297.3 & 203.1 & 249.1 \\
NEO & ESI+ & 4.10 & 400.3 & 185.1 & 305.2 \\
3-AcDON & ESI+ & 5.00 & 339.1 & 203.1 & 137.0 \\
15-AcDON & ESI+ & 5.00 & 339.1 & 136.9 & 261.1 \\
DAS & ESI+ & 7.06 & 384.3 & 307.2 & 247.2 \\
HT-2 & ESI+ & 8.91 & 442.4 & 215.1 & 263.2 \\
T-2 & ESI+ & 10.27 & 484.4 & 185.1 & 215.2 \\
ZEA & ESI- & 11.30 & 317.2 & 131.0 & 174.9 \\
FB1 & ESI+ & 10.20 & 722.4 & 334.2 & 352.2 \\
FB2 & ESI+ & 12.70 & 706.4 & 318.2 & 336.2 \\
\hline
\end{tabular}

DON: deoxynivaleol; NEO: neosolaniol; 3-AcDON: 3-acetyldeoxynivalenol; 15-AcDON: 15-acetyldeoxynivalenol; DAS: diacetoxyscirpenol; ZEA: zearalenone; FB1: fumonisin $\mathrm{B}_{1}$; FB2: fumonisin $\mathrm{B}_{2}$; ESI: electrospray ionization.

\subsection{Method Validation}

The limit of detection (LOD) of the single analytes was determined at a signal-to-noise ratio of 3:1. A value 3.3 times the LOD was selected as the LOQ. The recoveries and precision were tested using maize and wheat samples spiked with Fusarium toxins at the concentration levels of 50,100, and $500 \mu \mathrm{g} / \mathrm{kg}$.

The linearity of the method was tested in the concentration range of $50-500 \mu \mathrm{g} / \mathrm{kg}$ using matrix-matched standard solutions analysed in triplicates. Good linearity was proven for all analytes with correlation coefficients higher than 0.997. The accepted limit of detection (LOD) and the limit of quantification (LOQ) of all single Fusarium toxins were $15 \mu \mathrm{g} / \mathrm{kg}$ and $50 \mu \mathrm{g} / \mathrm{kg}$, respectively. The mean recoveries of single toxins determined in maize at the tested concentration levels were between $90 \%$ and $117 \%$. The recoveries were between $87 \%$ and $112 \%$ in wheat, except for DON, which was $124 \%$. The reproducibility expressed as $\operatorname{RSD}_{\mathrm{R}}$ was less than $16 \%$ for all Fusarium toxins in maize and $\leq 30 \%$ for all Fusarium toxins in wheat. The reproducibility and mean recoveries of the toxins were in line with the criteria given in Commission Regulation (EC) No 401/2006 and its amendments [53] except the recovery of DON which slightly exceeded the required value. 


\section{Conclusions}

In the study, the results of determination of ten Fusarium toxins in 125 samples from two seasons were obtained. They represent the very first insight into their occurrence in cereal commodities from Albania and a contribution to the knowledge on the issue in southern Europe.

Relevant Fusarium toxins in the region seem to be DON and FBs. Other toxins were detected in only a few samples (ZEA, T-2) or not at all (3-AcDON, 15-AcDON, HT-2, DAS, and NEO). The incidence was comparable with those reported in the neighbouring countries, but the FB concentrations in maize were significantly higher than reported elsewhere.

The incidence of mycotoxins in the samples from the Korça region seem lower than with the samples from the other investigated western plain regions close to the Adriatic Sea. Considering that the level of agricultural development is similar in all investigated regions, the lower incidence can be explained by the climate differences between temperate climate Korça and typical Mediterranean climate regions of the western part of the country.

A significant difference between the data from the years 2014 and 2015 indicates that data from further harvesting years need to be provided to adequately characterize the occurrence of Fusarium toxins in cereal grains in Albania. However, with regard to the incidence rates and the concentrations of DON and FBs, farmers should consider all principles of good agricultural practices including tillage, crop rotation, cultivar selection, planting date, irrigation and fertilisation regimes, insecticide/fungicide treatments, harvest timing, as well as drying, cleaning, segregation, and the storage of cereals under controlled conditions in order to reduce mycotoxin contamination and to ensure safe food and feed.

Author Contributions: Conceptualization, D.T., B.J.-S. and G.T.-K.; methodology, K.P.-V. and J.B.; validation, J.B.; formal analysis, K.P.-V. and J.B.; investigation, D.T. and G.T.-K.; data curation, D.T. and G.T.-K.; writing—original draft preparation, D.T.; writing—review and editing, D.T., J.B., K.P.-V., B.J.-S. and G.T.-K.; visualization, J.B. and G.T.-K.; supervision, G.T.-K. All authors have read and agreed to the published version of the manuscript.

Funding: The study was supported by the Slovenian Research Agency grant P4-0092 and by Erasmus Mundus programme of the European Union. The APC was funded by Slovenian Research Agency grant P4-0092.

Data Availability Statement: Not available.

Acknowledgments: The authors thank Karin Šrimpf and Irena Indihar for support with performing the chemical analyses.

Conflicts of Interest: The authors declare no conflict of interest.

Sample Availability: Not available.

\section{References}

1. Bennett, J.W.; Klich, M. Mycotoxins. Clin. Microbiol. Rev. 2003, 16, 497-516. [CrossRef] [PubMed]

2. Bräse, S.; Encinas, A.; Keck, J.; Nising, C.F. Chemistry and biology of mycotoxins and related fungal metabolites. Chem. Rev. 2009, 109, 3903-3990. [CrossRef] [PubMed]

3. Marin, S.; Ramos, A.J.; Cano-Sancho, G.; Sanchis, V. Mycotoxins: Occurence, toxicology, and exposure assessment. Food Chem. Toxicol. 2013, 60, 218-237. [CrossRef] [PubMed]

4. Ferrigo, D.; Raiola, A.; Causin, R. Fusarium toxins in cereals: Occurrence, legislation, factors promoting the appearance and their management. Molecules 2016, 21, 627. [CrossRef] [PubMed]

5. Neme, K.; Mohammed, A. Mycotoxin occurrence in grains and the role of postharvest management as a mitigation strategies. A review. Food Control 2017, 78, 412-425. [CrossRef]

6. Agriopoulou, S.; Stamatelopoulou, E.; Varzakas, T. Advances in occurrence, importance, and mycotoxin control strategies: Prevention and detoxification in foods. Foods 2020, 9, 137. [CrossRef] [PubMed]

7. Arce-López, B.; Lizarraga, E.; Vettorazzi, A.; González-Peñas, E. Human biomonitoring of mycotoxins in blood, plasma and serum in recent years: A review. Toxins 2020, 12, 147. [CrossRef] [PubMed]

8. Zhang, X.; Li, G.; Wu, D.; Liu, J.; Wu, Y. Recent advances on emerging nanomaterials for controlling the mycotoxin contamination: From detection to elimination. Food Front. 2020, 1-23. [CrossRef] 
9. Udovicki, B.; Audenaert, K.; De Saeger, S.; Rajkovic, A. Overview on the mycotoxins incidence in Serbia in the period $2004-2016$. Toxins 2018, 10, 279. [CrossRef]

10. Liu, Y.; Yamdeu, J.H.G.; Gong, Y.Y.; Orfila, C. A review of postharvest approaches to reduce fungal and mycotoxin contamination of foods. Compr. Rev. Food Sci. Food Saf. 2020, 19, 1521-1560. [CrossRef]

11. Perrone, G.; Ferrara, M.; Medina, A.; Pascale, M.; Magan, N. Toxigenic fungi and mycotoxins in a climate change scenario: Ecology, genomics, distribution, prediction and prevention of the risk. Microorganisms 2020, 8, 1496. [CrossRef] [PubMed]

12. Placinta, C.M.; D'Mello, J.P.F.; Macdonald, A.M.C. A review of worldwide contamination of cereal grains and animal feed with Fusarium mycotoxins. Anim. Feed Sci. Technol. 1999, 78, 21-37. [CrossRef]

13. Bhatnagar, D.; Payne, G.; Klich, M.; Leslie, J.F. Identification of toxigenic Aspergillus and Fusarium species in the maize grain chain In Mycotoxin Reduction in Grain Chains; Leslie, J.F., Logrieco, A.F., Eds.; John Wiley \& Sons: Ames, IA, USA, 2014 ; pp. 11-25.

14. Moretti, A.; Waalwijk, C.; Geisen, R. Identification of Fusarium spp. and Penicillium verrucosum in the Wheat Grain Chain. In Mycotoxin Reduction in Grain Chains; Leslie, J.F., Logrieco, A.F., Eds.; John Wiley \& Sons: Ames, IA, USA, 2014 ; pp. 151-168.

15. Alshannaq, A.; Yu, J.-H. Occurrence, toxicity, and analysis of major mycotoxins in food. Int. J. Environ. Res. Public Health 2017, 14, 632. [CrossRef] [PubMed]

16. Bottalico, A.; Perrone, G. Toxigenic Fusarium species and mycotoxins associated with head blight in small-grain cereals in Europe. Eur. J. Plant Pathol. 2002, 108, 611-624. [CrossRef]

17. Torres, A.M.; Palacios, S.A.; Yerkovich, N.; Palzzini, J.M.; Battilani, P.; Leslie, J.F.; Logrieco, A.F.; Chulze, S.N. Fusarium head blight and mycotoxins in wheat: Prevention and control strategies across the food chain. World Mycotoxin J. 2019, 12, 333-355. [CrossRef]

18. Nathanail, A.V.; Syvähuoko, J.; Malachova, A.; Jestoi, M.; Varga, E.; Michlmayr, H.; Adam, G.; Sieviläinen, E.; Berthiller, F.; Peltonen, K. Simultaneous determination of major type A and B trichothecenes, zearalenone and certain modified metabolites in Finnish cereal grains with a novel liquid chromatography-tandem mass spectrometric method. Anal. Bioanal. Chem. 2015, 407, 4745-4755. [CrossRef] [PubMed]

19. Eskola, M.; Kos, G.; Elliott, C.; Hajšlová, J.; Mayar, S.; Krska, R. Worldwide contamination of food-crops with mycotoxins: Validity of the widely cited 'FAO estimate' of 25\%. Crit. Rev. Food Sci. Nutr. 2020, 60, 2773-2789. [CrossRef]

20. Griessler, K.; Rodrigues, I.; Handl, J.; Hofstetter, U. Occurrence of mycotoxins in Southern Europe. World Mycotoxin J. 2010, 3, 301-309. [CrossRef]

21. Cheli, F.; Pinotti, L.; Rossi, L.; Dell'Orto, V. Effect of milling procedure on mycotoxin distribution in wheat fractions: A review. LWT Food Sci. Technol. 2013, 54, 307-314. [CrossRef]

22. Tibola, C.S.; Fernandes, J.M.C.; Guarienti, E.M.; Nicolau, M. Distribution of Fusarium mycotoxins in wheat milling process. Food Control 2015, 53, 91-95. [CrossRef]

23. Scudamore, K.A. Fate of fusarium mycotoxins in the cereal industry: Recent UK studies. World Mycotoxin J. 2008, 1, 315-323. [CrossRef]

24. Milani, J.; Maleki, G. Effects of processing on mycotoxin stability in cereals. J. Sci. Food Agric. 2014, 94, 2372-2375. [CrossRef] [PubMed]

25. Karlovsky, P.; Suman, M.; Berthiller, F.; De Meester, J.; Eisenbrand, G.; Perrin, I.; Oswald, I.P.; Speijers, G.; Chiodini, A.; Recker, T.; et al. Impact of food processing and detoxification treatments on mycotoxin contamination. Mycotoxin Res. 2016, 32, 179-205. [CrossRef]

26. Pinotti, L.; Ottoboni, M.; Giromini, C.; Dell'Orto, V.; Cheli, F. Mycotoxin contamination in the EU feed supply chain: A focus on cereal byproducts. Toxins 2016, 8, 45. [CrossRef]

27. Janić Hajnal, E.; Čolović, R.; Pezo, L.; Orčić, D.; Vukmirović, Đ.; Mastilović, J. Possibility of Alternaria toxins reduction by extrusion processing of whole wheat flour. Food Chem. 2016, 213, 784-790. [CrossRef] [PubMed]

28. Pereira, V.L.; Fernandes, J.O.; Cunha, S.C. Mycotoxins in cereals and related foodstuffs: A review on occurrence and recent methods of analysis. Trends Food Sci. Technol. 2014, 36, 96-136. [CrossRef]

29. European Commission. Commission Regulation (EC) No 1126/2007 of 28 September 2007 amending Regulation (EC) No $1881 / 2006$ setting maximum levels for certain contaminants in foodstuffs as regards Fusarium toxins in maize and maize products. Off. J. Eur. Union 2007, 255, 14-17.

30. European Commission. Commission Regulation (EC) No 1881/2006 of 19 December 2006 setting maximum levels for certain contaminants in foodstuffs. Off. J. Eur. Union 2006, 364, 5-24.

31. European Commission. Commission Recommendation 2013/165/EU of 27 March 2013 on the presence of T-2 and HT-2 toxin in cereals and cereal products. Off. J. Eur. Union 2013, 91, 12-15.

32. Cendoya, E.; Chiotta, M.L.; Zachetti, V.; Chulze, S.N.; Ramirez, M.L. Fumonisins and fumonisin-producing Fusarium occurrence in wheat and wheat by-products: A review. J. Cereal Sci. 2018, 80, 158-166. [CrossRef]

33. Manova, R.; Mladenova, R. Incidence of zearalenone and fumonisins in Bulgarian cereal production. Food Control 2009, 20, 362-365. [CrossRef]

34. Jakovac-Strajn, B.; Pavšič-Vrtač, K.; Ujčič-Vrhovnik, I.; Vengušt, A.; Tavčar-Kalcher, G. Microbiological and mycotoxicological contamination in Slovenian primary grain production. Toxicol. Environ. Chem. 2010, 92, 1551-1563. [CrossRef]

35. Cano-Sancho, G.; Valle-Algarra, F.M.; Jiménez, M.; Burdaspal, P.; Legarda, T.M.; Ramos, A.J.; Sanchis, V.; Marín, S. Presence of trichothecenes and co-occurrence in cereal-based food from Catalonia (Spain). Food Control 2011, 22, 490-495. [CrossRef] 
36. EFSA, European Food Safety Authority. Scientific Opinion on the risks for public health related to the presence of zearalenone in food. EFSA J. 2011, 9, 2197. [CrossRef]

37. Škrbić, B.; Malachova, A.; Živančev, J.; Veprikova, Z.; Hajšlová, J. Fusarium mycotoxins in wheat samples harvested in Serbia: A preliminary survey. Food Control 2011, 22, 1261-1267. [CrossRef]

38. Ibáñez-Vea, M.; Lizarraga, E.; Gonzáles-Peñas, E.; López de Cerain, A. Co-occurrence of type-A and type-B trichothecenes in barley from a northern region of Spain. Food Control 2012, 25, 81-88. [CrossRef]

39. Serrano, A.B.; Font, G.; Ruiz, M.J.; Ferrer, E. Co-occurrence and risk assessment of mycotoxins in food and diet from Mediterranean area. Food Chem. 2012, 135, 423-429. [CrossRef]

40. Stanković, S.; Lević, J.; Ivanović, D.; Krnjaja, V.; Stanković, G.; Tančić, S. Fumonisin B 1 and its co-occurrence with other fusariotoxins in naturally-contaminated wheat grain. Food Control 2012, 23, 384-388. [CrossRef]

41. Van Der Fels-Klerx, H.J.; Klemsdal, S.; Hietaniemi, V.; Lindblad, M.; Ioannou-Kakouri, E.; Van Asselt, E.D. Mycotoxin contamination of cereal grain commodities in relation to climate in North West Europe. Food Addit. Contam. Part A 2012, 29, 1581-1592. [CrossRef]

42. Alexa, E.; Dehelean, C.A.; Poiana, M.-A.; Radulov, I.; Cimpean, A.-M.; Bordean, D.-M.; Tulcan, C.; Pop, G. The occurrence of mycotoxins in wheat from western Romania and histopatological impact as effect of feed intake. Chem. Cent. J. $2013,7,99$. [CrossRef]

43. Juan, C.; Ritieni, A.; Mañes, J. Occurrence of Fusarium mycotoxins in Italian cereal and cereal products from organic farming. Food Chem. 2013, 141, 1747-1755. [CrossRef] [PubMed]

44. Pleadin, J.; Vahčić, N.; Perši, N.; Ševelj, D.; Markov, K.; Frece, J. Fusarium mycotoxins' occurrence in cereals harvested from Croatian fields. Food Control 2013, 32, 49-54. [CrossRef]

45. Uhlig, S.; Sundstøl Eriksen, G.; Skow Hofgaard, I.; Krska, R.; Beltrán, E.; Sulyok, M. Faces of a changing climate: Semi-quantitative multi-mycotoxin analysis of grain grown in exceptional climatic conditions in Norway. Toxins 2013, 5, 1682-1697. [CrossRef] [PubMed]

46. Alkadri, D.; Rubert, J.; Prodi, A.; Pisi, A.; Manes, J.; Soler, C. Natural co-occurrence of mycotoxins in wheat grains from Italy and Syria. Food Chem. 2014, 157, 111-118. [CrossRef]

47. Kirinčič, S.; Škrjanc, B.; Kos, N.; Kozolc, B.; Pirnat, N.; Tavčar-Kalcher, G. Mycotoxins in cereals and cereal products in SloveniaOfficial control of foods in the years 2008-2012. Food Control 2015, 50, 157-165. [CrossRef]

48. Bryła, M.; Waśkiewicz, A.; Podolask, G.; Szymczyk, K.; Jędrzejczak, R.; Damaziak, K.; Sułek, A. Occurrence of 26 mycotoxins in the grain of cereals cultivated in Poland. Toxins 2016, 8, 160. [CrossRef] [PubMed]

49. Gagiu, V.; Mateescu, E.; Armeanu, I.; Dobre, A.A.; Smeu, I.; Cucu, M.E.; Oprea, O.A.; Iorga, E.; Belc, N. Post-harvest contamination with mycotoxins in the context of the geographic and agroclimatic conditions in Romania. Toxins 2018, 10, 533. [CrossRef]

50. Udovicki, B.; Djekic, I.; Stankovic, S.; Obradovic, A.; Rajkovic, A. Impact of climatic conditions on fumonisins in maize grown in Serbia. World Mycotoxin J. 2019, 12, 183-190. [CrossRef]

51. FAOSTAT. Food and Agriculture Data. Crops. Production. 2020. Available online: http://www.fao.org/faostat/en/\#data/QC (accessed on 28 November 2020).

52. Battilani, P.; Logrieco, A.F. Global Risk Maps of Mycotoxins in wheat and Maize. In Mycotoxin Reduction in Grain Chains; Leslie, J.F., Logrieco, A.F., Eds.; John Wiley \& Sons: Ames, IA, USA, 2014; pp. 309-326.

53. European Commission. Commission Regulation (EC) No 401/2006 of 23 February 2006 laying down the methods of sampling and analysis for the official control of the levels of mycotoxins in foodstuffs. Off. J. Eur. Union 2006, 70, 12-34.

54. Topi, D.; Tavčar-Kalcher, G.; Pavšič-Vrtač, K.; Babič, J.; Jakovac-Strajn, B. Alternaria mycotoxins in grains from Albania: Alternariol, alternariol monomethyl ether, tenuazonic acid and tentoxin. World Mycotoxin J. 2019, 12, 89-99. [CrossRef]

55. Rasmussen, R.R.; Storm, I.M.L.D.; Rasmussen, P.H.; Smedsgaard, J.; Nielsen, K.F. Multi-mycotoxin analysis of maize silage by LC-MS/MS. Anal. Bioanal. Chem. 2010, 397, 765-776. [CrossRef] [PubMed]

56. Lattanzio, V.M.T.; Della Gatta, S.; Suman, M.; Visconti, A. Development and in-house validation of a robust and sensitive solidphase extraction liquid chromatography/tandem mass spectrometry method for the quantitative determination of aflatoxins $B_{1}$, $\mathrm{B}_{2}, \mathrm{G}_{1}, \mathrm{G}_{2}$, ochratoxin A, deoxynivalenol, zearalenone, T-2 and HT-2 toxins in cereal-based foods. Rapid Commun. Mass Spectrom. 2011, 25, 1869-1880. [PubMed]

57. Schenzel, J.; Forrer, H.R.; Vogelgsang, S.; Bucheli, T.D. Development, validation and application of a multi-mycotoxin method for the analysis of whole wheat plants. Mycotoxin Res. 2012, 28, 135-147. [CrossRef] [PubMed] 